\title{
IMPROVING STUDENTS' SPEAKING SKILL BY USING ROUND ROBIN BRAINSTORMING TECHNIQUE TO THE ELEVENTH MIA GRADE STUDENTS OF SMA DELI MURNI BANDAR BARU
}

\author{
Herni Yanti Firteach Gea, Jontra Jusat Pangaribuan, Novalina Sembiring \\ Catholic University of Saint Thomas \\ Email : novalina_sembiring@ust.ac.id
}

\begin{abstract}
Speaking is one of four basic skills in language. Speaking becomes the most important tool to communicate which needs to be accomplished. The objectives of this research are to describe the students' responses and how well are the students' speaking skill of the eleventh MIA grade students of SMA Deli Murni Bandar Baru after having been taught by using Round Robin Brainstorming Technique. This research is a Classroom Action Research which was conducted by applying Round Robin Brainstorming Technique to the eleventh MIA grade students class A. After eight meetings, it could be seen that there is a significant improvement of students' speaking skill. The result of this research showed that the students' responses after being taught by using Round Robin Brainstorming Technique are very good. The result is $91,84 \%$ students strongly agree that Round Robin Brainstroming Technique improve their speaking skill. The result of the test showed that the students' mean score in pretest is 58,58 with $16 \%$ of the students got score $\geq 75$ and in posttest mean score is 76,06 with $68 \%$ of the students got score $\geq 75$. It showed that there was a significant mean score improvement between pretest and posttest about 52\%. It is suggested that teachers use Round Robin Brainstorming Technique as an alternative technique in teaching speaking to the students in Senior High School in order to improve their speaking skill.
\end{abstract}

Keywords: Speaking skill, the Round Robin Brainstorming Technique

\section{INTRODUCTION}

\subsection{The Background of the Study}

Language has important roles in our daily lives. People express their opinion, feeling and thought through language. Language is used as a medium to interact with one another and fulfill our daily needs. People use language to deliver information in their daily lives.

In our country, Indonesia, most people communicate in Indonesian language in their daily activities. People must master a language to be able to communicate so that they can receive and give the information to one another. In this globalization era, English is one of the languages used in Indonesia. As we know that English is also an international language in the world so every country in this world studies about it. In Indonesia, English is taught as a foreign language.

English has important meanings for students to develop science, technology, culture, and art. The final objective of teaching and learning a language is able to communicate in that language. Teaching and learning will be successful if supported by some factors such as the method, approach, technique, completeness of teaching facilitation, interesting media, and condition of school environment. 
Teaching English in Indonesia is more difficult during the lesson because English is still a foreign language. Some students have studied English since they were in kindergarten, or in elementary school. Although they have studied English for such a long time, they still have so many difficulties in learning the subject.

Some of the difficulties faced by the students make them passive when they get the English subject in their class. This is a task for the English teachers to make their students to be active. Because of that, the teachers should make some interesting ways to teach English subject so the students will be more active in learning process. Some ways such as English debate, storytelling, and speech are usually used interesting students in learning English. Through them, they can communicate freely in English with their friends. They can improve their English skill, especially speaking skill by increasing the new vocabulary and making fun with English.

Speaking is a kind of either productive or active skill. Though the four skills are equally important, speaking becomes the most important tool to communicate that needs to be accomplished. In other words, the goal of language learning is communication and the aim of speaking in a language context is to promote efficient communication.

The success of speaking activity can be seen from some characteristics where the learners more active to talk. Syafryadin, et al. (2013:75) state that firstly, the characteristic in determining of successful speaking activity is the learners have to be talkative. Secondly, the students can be called successful in speaking activity, if the students have good participation in speaking class. Thirdly, the students have good or high motivation in speaking. Fourthly, the students express themselves in utterance that is relevant, comprehensible to each other and acceptable with language fluency or accuracy.

As language learners who have learned English, the students should be able to interact orally with each other through English. Unfortunately, in the real teaching and learning of speaking to grade XI MIA students of SMA Deli Murni Bandar Baru, most of the students have difficulty in their speaking production. MIA stands for Matematika dan Ilmu Alam. According to the teacher, Mrs. Sry Br Ginting, the students often have difficulty in expressing ideas and opinions as they are afraid of making errors and not confident to speak English. Besides, they also have inadequate ability in mastering the English vocabulary and functional expressions so that they have no idea to speak. Furthermore, the students also have poor competencies in grammar so that they prefer to keep silent and some of them never share their opinions in the learning activities. It can be also seen by their mean score in speaking 71,68 which is showed by the English teacher. The students could not reach the Minimum Score Criteria $\geq 75$, so it can be concluded that the students' speaking skills are low.

Based on the problems above, the writer wants to solve the problems by improving the speaking skills' of grade XI MIA students of SMA Deli Murni Bandar Baru through Round Robin Brainstorming technique. This technique forms a small group and each group consists of four or six members. Next, all groups make around. Then, each member will share about a topic which is determined by the teacher. Thus, this technique will make students have a chance to speak out. It indicates that each member will propose his or her opinion about the topic in their own group.

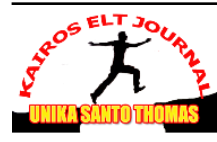


Round Robin Brainstorming technique will encourage students' interaction and also minimize the grammatical mistakes in speaking as the teachers will give their feedback at the end of the meeting. The students as the speakers also talk about the same topics which are chosen several times, so it makes them easy to remember and pronounce the same words. It indicates they will study the new vocabularies, try to pronounce, and memorize it while talk about their opinions about the topic.

The writer assumes that Round Robin Brainstorming technique is the best way to maximize the students' chance to speak out. Students can be motivated to express their ideas and opinions to strengthen their ideas about the topic. It also motivates them to be active in speaking and all the group members will do all the work. According to Kagan (1994) Round Robin Brainstorming has some strengths in improving students' speaking skill. First, when group activities are used, one student per group is speaking. Second, positive interdependence is the feeling among group of students that what helps other members. Third, one of the most commonly heard objections for having students work under Round-Robin technique is some group members will do all the work. Fourth, to encourage each member to play an important role in the group and benefit from the group effort, Round-Robin Brainstorming technique seeks to equalize participation.

The writer choose this technique because some research findings have shown the good results of teaching speaking by using Round Robin Brainstorming technique. The first research has been done by Syafryadin, et al. (2013) with the title 'Improving Grade X Students' Speaking Achievement under Round Robin Technique". They stated that Round Robin technique can improve the students' speaking achievement at grade $\mathrm{X}$ especially in accuracy. It can be proved from the mean score from cycle one to cycle two. In cycle one, the mean score is only 67.30, while at the end of cycle two the mean score of students' accuracy is 72.7.

The second research has been done by Sulaiman (2016) with the title 'Improving Students' Speaking Skill by Using Round Robin Technique at the second grade of Madrasah Tsanawiyah Muhammadiyah Gobah Kampar Regency" which shows a good result. In the cycle 1 there are no students pass the test, so $100 \%$ fail. Then, in the cycle 2 there are improvement to students' learning, there are 9 students pass with $53 \%$ and 8 Students fail with $47 \%$. He concludes that Round Robin technique is successful to improve students' speaking skill.

Based on the explanation, the writer is interested in conducting a research entitled 'Improving Students' Speaking Skill by Using Round Robin Brainstorming Techniques to the Eleventh MIA A Grade Students of SMA Deli Murni Bandar Baru". It is expected that The Round Robin Brainstorming Technique can improve students' speaking skill.

\section{REVIEW OF LITERATURE}

\subsection{Speaking Skills}

In learning English, there are four skills : listening, speaking, reading and writing. From four of language skills, speaking becomes the basic skill must be mastered by the students when they learn English in order to communicate with the other people. According to Nunan (1998: 39) "Speaking is the single most important aspect of learning a second or foreign language and success is measured in terms of the ability to carry out a conversation in the language". Speaking is the

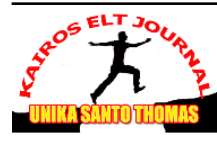


goal to interact with the other people in English, especially for the Senior High School students who should learn English.

Brown (2004: 140) defines "Speaking as a productive skill that can be directly and empirically observed, because listening and speaking are almost always closely interrelated". From this statement, the writer can conclude that speaking is an activity which has a relation with listening where speaking as an oral production compromises the reliability and validity of an oral production test.

Teaching speaking means teaching the productive skill. Teaching productive skill is teaching the microskills and macroskills. Brown (2004: 142-143) states, "The microskills refer to producing the smaller chunks of language such as phonemes, morphemes, words, collocations, and phrasal units. The macroskills imply the speaker's focus on the larger elements: fluency, discourse, function, style, cohesion, nonverbal communication, and strategic options". The micro- and macroskills total roughly 16 different objectives to asses in speaking. However here below, some of the pertinent to this research are presented:

\section{Microskills}

1. Produces differences among English phonemes and allophonic variants.

2. Produce chunks of language of different lengths.

3. Produce English stress patterns, words in stressed and unstressed positions rhythmic structure, and intonation contours.

4. Produce reduced forms of words and phrases.

5. Use an adequate number of lexical units (words) to accomplish pragmatic purpose.

6. Produce fluent speech at different rates of delivery.

7. Monitor one's own oral production and use various strategic devices pauses, fillers, self-corrections, backtracking- to enhance the clarity of the message.

8. Use grammatical word classes (nouns, verbs, etc), system (e.g. tense, agreement, and pluralization), word order, patterns, rules, and elliptical forms.

9. Produce speech in natural constituents: in appropriate phrases, pause groups, breath groups, and sentence constituents.

10. Express a particular meaning in different grammatical forms.

11. Use cohesive devices in spoken discourse.

\section{Macroskills}

12. Appropriately accomplish communicative functions according to the situation, participants and goals.

13. Use appropriate styles, registers, implicature, redundancies, pragmatic conventions, conversation rules, floor-keeping and yielding, interrupting, and other sociolinguistics features in face to face conversations.

14. Convey links and connections between events and communicate such relations as focal and peripheral ideas, events and feelings, new information and given information, generalization, and exemplification.

15. Convey facial features, kinesics, body languages, and other non verbal cues along with verbal language.

16. Develop and use a battery of speaking strategies such as emphasizing key words, rephrasing, providing a context for interpreting the meaning of words, 
appealing for help, and accurately assessing how well your interlocutor is understanding you.

From some definitions above it can be concluded that speaking skill is always related to communication. Speaking skill itself can be stated as the skill to use the language accurately to express meanings in order to transfer or to get knowledge and information from other people in the whole life situation.

\subsection{Types of Speaking Performances}

Based on Brown (2004:141-142) there are five taxonomies which are emerged for oral production:

\section{Imitative}

At one end of a continuum of types of speaking performance is the ability to simply parrot back (imitative) a word or phrase or possibly a sentence. While this is a purely phonetic level of oral production, a number of prosodic, lexical, and grammatical properties of language maybe included in the criterion performance. The writer conclude that imitative emphasize on pronunciation so it focus on repetition of words level and if it is possible to sentences level.

The example of imitative:

Teacher : Repeat after me: Beat [pause] bit [pause]

\section{Intensive}

A second type of speaking frequently employed in assessment contexts is the production of short stretches of oral language designed to demonstrate competence in a narrow band of grammatical, phrasal, lexical, or phonological relationship. From the explanation above the writer conclude that intensive focus on pronunciation and fluency. Example of intensive is reading aloud. By reading aloud the teacher knows the ability of students in pronunciation and fluency while reading a text.

\section{Responsive}

Responsive assessment task include interaction and test comprehension but at the somewhat limited level of very short conversations, standard greetings and small talk, simple requests and comments, and the like. So the writer concludes that responsive means how the students can respond question, instruction, and request by others.

Example:

A: what do you think about the weather today?

B: It's so cold.

\section{Interactive}

The difference between responsive and interactive speaking is in the length and complexity of the interaction, which sometimes includes multiply exchanges and/or multiply participants. The writer gets a point that interactive has more complexity in interaction than responsive because in interactive the speaker should be able to interact based on the situation, so the speaker need to think hard. The examples of interactive such as interview and role play.

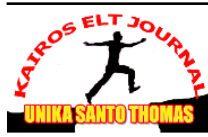




\section{Extensive (Monologue)}

Extensive oral production task include speeches, oral presentation, and story-telling, during which the opportunity for oral interaction from listeners is either highly limited (perhaps two non verbal responses) or ruled out altogether.

In this study, the writer is going to do the interactive types of speaking performances in which the students present their ideas about the topic is chosen by the writer as the teacher and other students give their comment by stating their new ideas.

\subsection{Functions of Speaking}

Numerous attempts have been made to classify the functions of speaking in human interaction. Richard (2008:21) uses an expanded three-part version of Brown and Yule's framework: talk as interaction; talk as transaction; talk as performance. Each of these speech activities is quite distinct in terms of form and function and requires different teaching approaches.

1. Talk as interaction

Talk as interaction refers to what we normally mean by "conversation" and describes interaction that serves a primarily social function. When people meet, they exchange greetings, engage in small talk, recount recent experiences, and so, on because they wish to be friendly and to establish a comfortable zone of interaction with each other. The focus is more on the speakers and how they wish to present themselves to each other than on the message. In other words, talk as interaction means that people speak to interact with others. The example of talk as interaction:

Aleixia : Hi, Good morning Herni. How's life?

Herni : Hi, Good morning Aleixia. I am pretty well. Thank you. How about you?

\section{Talk as transaction}

Talk as transaction refers to situations where the focus is on what is said or done. The message and making oneself understood clearly and accurately is the central focus, rather than the participants and how they interact socially with each other. In other words, talk as transaction means that people talk to exchange the information or message clearly by each other. The example of talk as transaction: Herni : Hey, do you know that Sherly gets the highest score in Pragmatic subject? Aleixia : Oh, really? She is awesome. I want to see mine.

\section{Talk as performance}

The third type of talk that can usefully be distinguished has been called talk as performance. This refers to public talk, that is, talk that transmits information before an audience, such as classroom presentations, public announcements, and speeches.

\subsection{Teaching Speaking}

Related to teaching speaking, Brown (1994:268-269) notes seven principles for designing speaking techniques.

1. The teacher should use techniques that cover the spectrum of learner need for language-based focus on accuracy and message based focus on interaction, meaning, and fluency.

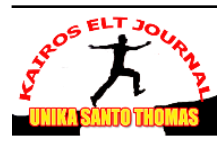


2. The teacher should provide motivating techniques which can encourage the students' motivation to learn English intrinsically.

3. The teacher should encourage the students to use authentic language during the speaking activities so that the activities will be meaningful for them.

4. When students make some mistakes during the activities the teacher should give appropriate feedback and correction so that they will not make the same mistakes in the following activities.

5. The teacher should integrate activity during speaking activity, because speaking and listening are assimilated.

6. The teacher should also give the students some opportunities to initiate oral communication by asking questions or engaging them in a conversation.

7. The teacher should encourage the students' development of speaking strategy because usually the students are not aware of developing their own personal strategy for accomplishing oral communication purpose.

From the explanation, we can see that all of principles for designing speaking techniques are very necessary. Its need is passing the examinations to move to the next level and graduate from the school, and the general requirement is the students are able to speak and hold conversations. From a communicative purpose, speaking is closely related to listening. The interaction between these two skills is also shown in the conversation.

\subsection{The Assessments of Speaking}

Speaking is complex skill requiring the simultaneous use of different ability which often develops at different roles. Speaking skill is generally recognized in analysis of speech processes which includes pronunciation, grammar, vocabulary, fluency and comprehension. Hughes (2003: 131) designs a scale to score speaking test. In the scale, the students are tested on pronunciation, grammar, vocabulary, and fluency. In this research the writer will measure two scales which included Pronunciation and fluency. Below is the speaking test scale stated by Hughes. The writer will use this scale to measure the students' speaking performances.

Table 1. Criteria of Pronunciation Proficiency

\begin{tabular}{|c|l|c|}
\hline NO & \multicolumn{1}{|c|}{ Proficiency Description } & Scale of score \\
\hline $\mathbf{1}$ & Pronunciation frequently unintelligible & $1,0-4,5$ \\
\hline $\mathbf{2}$ & $\begin{array}{l}\text { Frequent gross errors and very heavy accent make. } \\
\text { Understanding difficult, require frequent repetition. }\end{array}$ & $4,6-5,5$ \\
\hline $\mathbf{3}$ & $\begin{array}{l}\text { "Foreign accent" requires concentrated listening, and } \\
\text { mispronunciation lead to occasional } \\
\text { misunderstanding. Apparent errors in grammar and } \\
\text { vocabulary }\end{array}$ & $5,6-6,5$ \\
\hline
\end{tabular}




\begin{tabular}{|c|l|c|}
\hline $\mathbf{4}$ & $\begin{array}{l}\text { Market "Foreign accent" and occasional } \\
\text { mispronunciation which do not interfere with } \\
\text { misunderstanding. }\end{array}$ & $6,6-7,5$ \\
\hline $\mathbf{5}$ & $\begin{array}{l}\text { No conspicuous mispronunciations, but would not be } \\
\text { taken for a native speaker. }\end{array}$ & $7,6-8,5$ \\
\hline $\mathbf{6}$ & $\begin{array}{l}\text { Native pronunciation, with no trace of "Foreign } \\
\text { accent". }\end{array}$ & $8,6-10,0$ \\
\hline
\end{tabular}

Table 2. Criteria of Fluency Proficiency

\begin{tabular}{|c|l|c|}
\hline No & \multicolumn{1}{|c|}{ Proficiency Description } & Scale of score \\
\hline 1 & $\begin{array}{l}\text { Speech is too halting and fragmentary that conversation } \\
\text { is virtually impossible }\end{array}$ & $1,0-4,5$ \\
\hline 2 & $\begin{array}{l}\text { Speech is very slow and uneven except for short or } \\
\text { routine sentences }\end{array}$ & $4,6-5,5$ \\
\hline 3 & $\begin{array}{l}\text { Speech is frequently hesitant and jerky, sentences may } \\
\text { be left uncompleted }\end{array}$ & $5,6-6,5$ \\
\hline 4 & $\begin{array}{l}\text { Speech is occasionally hesitant, with some unevenness } \\
\text { caused by rephrasing and grouping for words. }\end{array}$ & $6,6-7,5$ \\
\hline 5 & $\begin{array}{l}\text { Speech is effortless and smooth, but perceptively } \\
\text { nonnative in speed and evenness. }\end{array}$ & $7,6-8,5$ \\
\hline 6 & $\begin{array}{l}\text { Speech on all professional and general topics as } \\
\text { effortless and smooth as a native speakers' }\end{array}$ & $8,6-10,0$ \\
\hline
\end{tabular}

\subsection{The Round Robin Brainstorming Technique}

Round Robin Brainstorming is a technique for generating and developing in a group brainstorming setting. It relies on an interactive process building off consecutive contributions by each participant, conducted in either written or verbal variations (Kagan, 2007). Essentially, Round Robin Brainstorming is team work in which every member of group generating ideas with elaborate and comment the ideas.

In his other book, Kagan (2009: 246) also says that "Round Robin Brainstorming is one of the simplest, yet most flexible, team building structures. In Round Robin Brainstorming, each teammate takes a turn sharing for preset amount of time".

According to Karre (2009:9) "Round Robin Brainstorming engages students in group discussion to develop ideas by the topics given by teacher. It means that Round Robin Brainstorming is one technique to improve students' speaking skill in class by group". A Round Robin Brainstorming is started by one person and then continued successively by others in turn. Whether a person can get 
additional turns, how many lines each person can contribute, and how it can be ended depend on the rules.

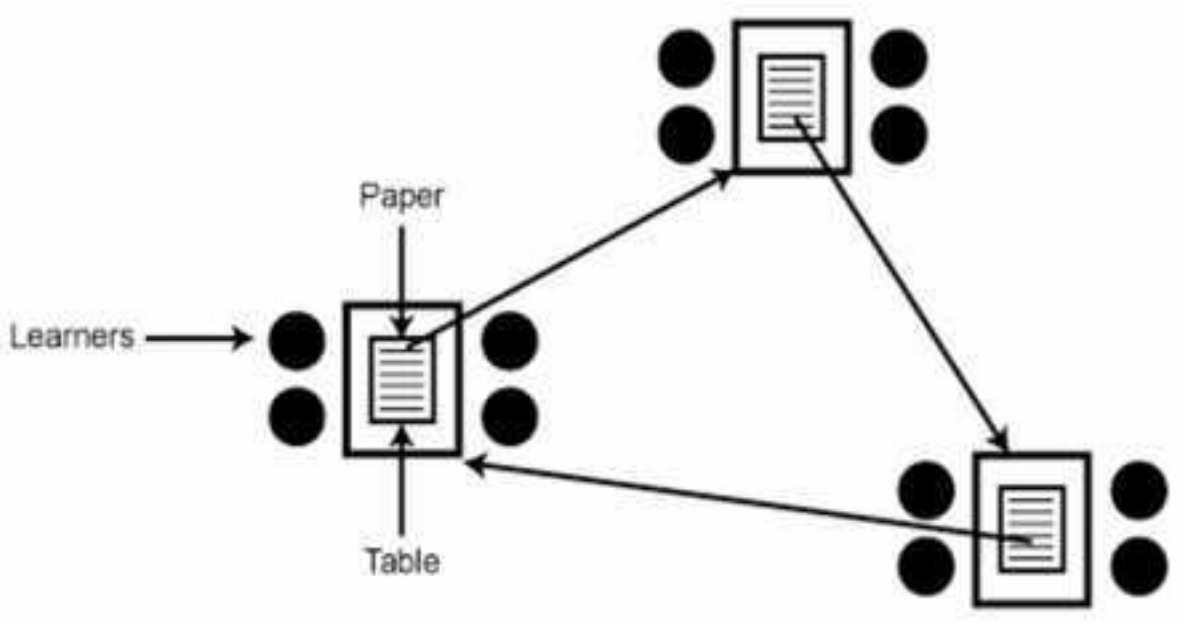

Figure 1.

\section{Illustration of Round Robin Brainstorming Technique Teaching Process}

From all definitions, the writer concludes that Round Robin Brainstorming is the technique of cooperative learning to exchange the ideas about the topics are given by the teacher in which all the students take turns to express their ideas to elaborate the topics clearly. The rule is every student must give the new ideas while given a chance to speak out in presenting their ideas, so in their group, they will be given time to discuss first to get the main idea so they can all take turns to speak out and share their new ideas.

\subsubsection{The Purpose of Round Robin Brainstorming}

Karre (2009:9) says "The purpose of Round Robin Brainstorming is to engage every student in the discussion by following a systematic structure for sharing". Students may offer new ideas in turn. Students may "pass" if they have nothing new to add at the time of their turn. Students may "pass" during one round and then offer an idea on the next. Passing does not eliminate students from the discussion. Passing simply indicates that a student has nothing new to add during this turn. The turn taking follows around the circle until the team exhausts all ideas and all students "pass" on their turn.

\subsubsection{The Advantages of Round Robin Brainstorming Technique}

Mandel (2009:98) states that there are some advantages of cooperative learning:

a. Cooperative learning develops high level thinking skill.

b. Skill building and practice can be enhanced and made less tedious though cooperative learning activities in and out classroom.

c. It creates can environment for active, involved and exploratory.

d. It improves the performance of the weaker students when grouped with higher achievement students.

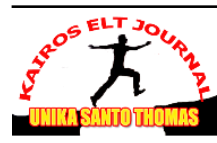


e. It addresses learning style different among students.

Meanwhile Leopard and Wells in Surati (2015: 27), there are two positive features of Round Robin Brainstorming. First, students can generate many example and ideas. Second, Round Robin Brainstorming provides an opportunity for students to explore new ideas. It means that Round Robin Brainstorming is a good technique to improve students' speaking skill because students have to express their ideas while they solve the problems according to the topics given. Round Robin Brainstorming also gives an opportunity for the students to answer the questions freely by using their own idea. Students are not afraid to make a mistake in speaking English. Therefore the Round Robin Brainstorming technique can improve students' self confidence.

Based on the advantages, the writer will apply this technique to find out the improvement of students speaking ability by using Round Robin Brainstorming Technique.

\subsubsection{The Procedures of Round Robin Brainstorming Technique}

Barkley et al. (2012:163) state that the procedures of Round Robin Brainstorming Technique in teaching speaking are as follows:

a. Ask the students in form groups of four or six

b. Explain that the purpose of brainstorming is to generate many ideas. Groups' members will take turns, moving clockwise. Inform students that they must not interrupt or inhibit the flow ideas.

c. If it would be beneficial for students to assume a role (such as recorder or rule enforces), allow a few moments for role assignment.

d. Tell students whether or not they will go around the group once or multiple times, announce a time limit, and pose the prompt.

e. Ask one student to begin the activity by stating an idea or answer aloud. The next student continues the brainstorming session by stating a new idea. The activities continue, moving from member to member in sequence, until all students have participated.

Based on the explanation, the writer concludes that the process of Round Robin Brainstorming Technique is simple to apply. Students are asked to form a group to discuss about a topic and taking their turns to generate many ideas and all students must be participated to state many ideas.

\section{RESEARCH METHOD}

\subsection{Research Design}

This research was classroom action research (CAR). Cresswell (2008:596) states that classroom action research is the most applied practical design action researcher to explore a practical problem with an aim toward developing a solution to a problem. It has an applied focus similar to mixed methods research; it used data collection based on quantitative or qualitative methods or both. Based on the explanation above, it could be concluded that the action research has potential to find out and develop the solutions for practical problems in the classroom. It means action research would also bring some improvements in practice. In this research study, the writer was participated in the research in order to solve the problems appeared in teaching and learning process of speaking and to bring improvements 
to the students' speaking skills to the eleventh MIA grade students of SMA Deli Murni Bandar Baru by using Round Robin Brainstorming Technique.

\subsection{The Location and Time of the Study}

This research was conducted at SMA Deli Murni Bandar Baru. It was located at Jl. Letjend Jamin Ginting Km 47 Bandar Baru- Sibolangit, and this school has been operating since 1993. The writer chose this school as the location of the research because the writer as the alumnus wanted to give a little contribution for this school so the students could improve their speaking skills and teachers of English could also use Round Robin Brainstorming technique to teach speaking skills. In addition, there was no similar study conducted at the school. This study would be conducted in April 2017.

\subsection{The Subject of the Study}

The subject of this study was the eleventh grade students of SMA Deli Murni Bandar Baru. There were 5 classes of the eleventh grade students. However, the writer took only one class as the subject of the study. The subject of the study was class eleventh MIA grade students which consisted of 25 students, 13 males and 12 females. The writer chose this class as the subject of the study because there was a problem in speaking skills of students in eleventh MIA grade.

\subsection{Types of Data}

The data of this research were quantitative and qualitative data. The quantitative data were in the form of the students' speaking performance scores while the qualitative data were in the forms of the descriptions of the process during the actions written in observation of teaching learning and respond of students.

\subsection{Procedures of Classroom Action Research}

This study used classroom action research. The writer used the model developed by Kemmis and McTaggart (Hopkins, 1993:48). There were four components in one cycle for conducting classroom action research, namely: planning, action, observation and reflection.

\section{RESEARCH FINDING AND DISCUSSION}

\subsection{Research Finding}

The finding of this research is the Round Robin Brainstorming technique can help students improve their speaking skill. By applying this technique, the score of the students in speaking kept increasing from the pre-test until post-test. It was proved by the data which showed that the mean of the students in post-test $(76,06)$ was higher than formative test II $(71,078)$, higher than formative test I $(65,04)$ and also higher than pre-test $(58,58)$.

The qualitative data which were taken from the questionnaires, observation sheet, and field notes also showed that students are interested in learning speaking by using Round Robin Brainstorming technique because this technique can be a solution for them who were not confident in speaking. The students enjoyed the speaking class and applied the technique well. The technique is very useful to help the students to improve their vocabulary because they would repeat some words and it made them memorize those words directly.

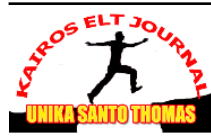


The questionnaires indicated the response of students during applying of Round Robin Brainstorming technique were strongly agree that this technique was interesting and suitable to improve speaking skill. Then from the observation sheets, there was significant progress that shown in every meeting, especially in cycle II. The students were enthusiastic, active, confident, and interested in learning speaking. Some of the students who did not like to study English were more interested to study English because they felt it was fun.

The Field notes indicated that the situation of teaching and learning process was better from the first meeting to the last meetings. Students were more active in teaching and learning process. The mispronunciation was reduced from cycle I to cycle II and students who got higher score from the first meeting showed the highly progressed in fluency.

\subsection{Discussion}

Round Robin Brainstorming technique was applied to improve students' speaking skill. It was one of the many techniques that could make the students interested to talk any ideas so it could make their speaking skill improved.

This research has proved the effectiveness of applying Round Robin Brainstorming technique. It was shown in the table 4.6, the students' score from pre-test, formative test, and post-test were increasing. It was because the teacher controlled class better, directly admonished the students who did not pay attention in learning process.

Students' data in post-test showed that the mean of students' scores were highest than the mean of the students' score in formative test I, formative test II and also better than pre-test, there were 17 students who got the score $\geq 75,8$ students who got the score $<75$ and the highest score was 85 . Students who got the score $<75$ were not the students who did not pay attention, they have tried to do their best but there were any different background of every students in speaking skills especially in fluency and pronunciation assessments.

The improvement not only happened in the mean of students' score but also the expression, interest, and excitement of students in speaking. Most of the students were more active during teaching and learning process started from cycle I to cycle II. They were more enthusiast and competitive to speak up and share their ideas about the topic given by teacher.

Questionnaires, observation sheets, and field notes also supported that the technique was able to improve students' speaking skill. It was shown by their response and attitude during the teaching and learning process. They were also more solid in their groups and helped their friends who did not know the English of some words. They have shared each other well in their groups and try to be the best groups. This technique also helped the weaker students to improve their achievement by the higher students' achievement in speaking.

Their fluency and pronunciation in speaking improve during the implementation of Round Robin Brainstorming technique in teaching and learning process. It was caused of this technique challenge students to speak up more and elaborate their ideas about topics who were chosen by teacher which was different in every meeting in cycle I and cycle II. Student were also given corrections by teacher at the end of teaching and learning process so they knew their mistaken in pronounce some words while speaking up.

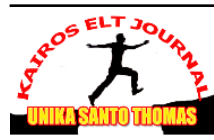


The hindrances of applying this technique were the class was being over noisy sometimes because some students in groups still discuss about new idea to challenge other groups. In addition, the new idea also came from the higher students' achievement in speaking. However, there were more advantages by using this technique. As a reflection, in the next time the teacher should also improve her ability in teaching learning process in speaking by using Round Robin Brainstorming technique and all students must be more active in speaking about their ideas, not only the students who got high score from the first meeting.

Based on the calculation and the analysis above, it infers that students have progressed in speaking skill especially in pronunciation and fluency after being given treatment by using Round Robin Brainstorming technique.

\section{CONCLUSIONS AND SUGGESTIONS \\ 5.1 Conclusions}

After presenting and analyzing data in the previous chapter, the writer accomplishes to the conclusion as follows:

1) The students' responses after being taught by using Round Robin Brainstorming Technique are very good. The questionnaires show that students strongly agree that Round Robin Brainstorming Technique is interesting and suitable to improve their speaking skill.

2) The result of the study shows that Round Robin Brainstorming technique of teaching speaking especially in pronunciation and fluency is able to help the students improve their speaking skill. The result of the action shows that students are more active, confident, interested, and enthusiastic. The students' mean score in pretest is 58,58 with $16 \%$ of the students got score $\geq 75$ and in posttest mean score is 76,06 with $68 \%$ of the students got score $\geq 75$. It shows that there is a significant mean score improvement between pretest and posttest about $52 \%$.

\subsection{Suggestions}

Based on the result of the study and conclusions, the writer is going to suggest as follows:

1) For the writer

The writer hopes that the result of the study makes the English teacher uses appropriate teaching model of Round Robin Brainstorming technique in improving students' speaking skill.

2) For the teacher

They can use the Round Robin Brainstorming technique in English teaching learning process especially in speaking skill. The teacher should make students enjoy speaking class. The teacher should give correction if students do mispronunciation and let them do many mistaken like grammar in speaking because they study from those mistakes.

3) For the students

Students should be active in teaching learning process and are not afraid to speak up.The students should also have high motivation and desire in improving their speaking ability.

4) For other researchers

It shows that the using of Round Robin Brainstorming technique can improve the students' speaking skill, so that the other researchers or the readers

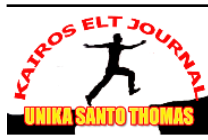


could use the method when they are learning speaking and to improve their speaking skill.

\section{BIBLIOGRAPHY}

Arikunto, Suharsimi. 2007. Penelitian Tindakan Kelas. Jakarta: Bumi Aksara Rineka Cipta. 2010. Prosedur Penelitian Suatu Pendidikan Praktik. Jakarta:

Barkley, Elizabert. et.al. 2012. Collaborative Learning Techniques. Bandung: Nusa Media.

Brown, H. Douglas. 1994. Teaching by Principles. New Jersey: Prentice Hall Regents Englewood Cliffs.

2004. Language Assessment: Principles and Classroom Practices. New York: Pearson Education.

Creswell, John W. 2008. Educational Research: Planning, Conducting, and Evaluating Quantitative and Qualitative Research. New Jersey: Pearson Education.

Dawson, Catherine. 2007. A Practical Guide to Research Methods. Oxford: How To Books.

Hopkins, David. 1993. A Teacher's Guide to Classroom Research. Bukingham, Philadelphia: Open University Press.

Hughes, Arthur. 2003. Testing for Language Teachers. Cambridge: Cambridge University Press.

Kagan, S. 1994. Cooperative Learning. San Juan Capistrano, CA: Kagan Cooperative Learning.

Kagan, S.et.al. 2007. Cooperative Learning. Retrieved on September 19, 2014 from http://wikipedia/language.com

Kagan, S. and Kagan, Miguel. 2009. Kagan Cooperative Learning. San Clamante: Kagan Publishing.

Karre, Idahlynn. 2009. Strategies, Busy, Noisy, and Powerfully Effective: Cooperative Learning in the College Classroom. Team-based Learning in the College Classroom, 1(3), 9-20.

Louis, Cohen. et.al. 2007. Research Methods in Education. New York: Routledge Publishing.

Mandel, Rita Rani. 2009. Cooperative Learning Strategies to Enhance Writing Skill. Modern Journal of Applied Linguistic, 1 (2), 98-100. 
Nunan, David. 1998. Second Language Teaching and Learning. New York: Heinle \& Heinle Publishers.

Richards, Jack C. 2008. Teaching Listening and Speaking. New York: Cambridge University Press.

Surati, Siti. 2015. Using Round Robin Brainstorming to Improve Students' Ability in Reading Narrative Text. An Unpublished Sarjana's Thesis, Faculty of Teachers Training and Education: IAIN Salatiga University.

Sulaiman, Meri. 2016. Improving Students'Speaking Skill by Using Round Robin Technique at the Second Grade of Madrasah Tsanawiyah Muhammadiyah Gobah Kampar Regency. An Unpublished Sarjana's Thesis, Faculty of Teachers Training and Education: UIN SUSKA Riau University.

Syafryadin, et al. 2013. Improving Students' Speaking Achievement Under Round Robin Technique. International Journal of Education, 1(1),75-96. 